\title{
Atovaquone and quinine anti-malarials inhibit ATP binding cassette transporter activity
}

\author{
Sanna R Rijpma', Jeroen JMW van den Heuvel', Maarten van der Velden ${ }^{1}$, Robert W Sauerwein², Frans GM Russel ${ }^{1}$ \\ and Jan B Koenderink ${ }^{*}$
}

\begin{abstract}
Background: Therapeutic blood plasma concentrations of anti-malarial drugs are essential for successful treatment. Pharmacokinetics of pharmaceutical compounds are dependent of adsorption, distribution, metabolism, and excretion. ATP binding cassette $(A B C)$ transport proteins are particularly involved in drug deposition, as they are located at membranes of many uptake and excretory organs and at protective barriers, where they export endogenous and xenobiotic compounds, including pharmaceuticals. In this study, a panel of well-established anti-malarial drugs which may affect drug plasma concentrations was tested for interactions with human $A B C$ transport proteins.
\end{abstract}

Methods: The interaction of chloroquine, quinine, artemisinin, mefloquine, lumefantrine, atovaquone, dihydroartemisinin and proguanil, with transport activity of P-glycoprotein (P-gp), breast cancer resistance protein (BCRP), bile salt export pump (BSEP) and multidrug resistance-associated proteins (MRP) 1-4 were analysed. The effect of the anti-malarials on the ATP-dependent uptake of radio-labelled substrates was measured in membrane vesicles isolated from HEK293 cells overexpressing the ABC transport proteins.

Results: A strong and previously undescribed inhibition of BCRP-mediated transport by atovaquone with a $50 \%$ inhibitory concentration $\left(\mathrm{IC}_{50}\right)$ of $0.23 \mu \mathrm{M}(95 \% \mathrm{Cl}$ 0.17-0.29 $\mu \mathrm{M})$ and inhibition of P-gp-mediated transport by quinine with an $\mathrm{IC}_{50}$ of $6.8 \mu \mathrm{M}(95 \% \mathrm{Cl} 5.9-7.8 \mu \mathrm{M})$ was observed. Furthermore, chloroquine and mefloquine were found to significantly inhibit P-gp-mediated transport. BCRP transport activity was significantly inhibited by all anti-malarials tested, whereas BSEP-mediated transport was not inhibited by any of the compounds. Both MRP1- and MRP3-mediated transport were significantly inhibited by mefloquine.

Conclusions: Atovaquone and quinine significantly inhibit BCRP- and P-gp- mediated transport at concentrations within the clinically relevant prophylactic and therapeutic range. Co-administration of these established anti-malarials with drugs that are BCRP or P-gp substrates may potentially lead to drug-drug interactions.

Keywords: ABC transporter, P-glycoprotein, BCRP, BSEP, MRP, Anti-malarial, Transport, Vesicle

\section{Background}

ATP binding cassette $(\mathrm{ABC})$ transporters are membranebound proteins that allocate a wide variety of compounds at the expense of ATP, even against steep concentration gradients [1]. P-glycoprotein (P-gp/ABCB1), bile salt export pump (BSEP/ABCB11), multidrug resistance-associated proteins (MRP1-4/ABCC1-4), and breast cancer resistance protein (BCRP/ABCG2) are among the most important drug transporters of the $\mathrm{ABC}$ protein family. $\mathrm{ABC}$ transport

\footnotetext{
* Correspondence: Jan.Koenderink@radboudumc.nl

'Department of Pharmacology and Toxicology, Radboud University Medical Centre, Nijmegen, Netherlands

Full list of author information is available at the end of the article
}

proteins are known for their capacity to protect the organism from potentially toxic xenobiotics through excretion, thereby decreasing intracellular concentrations. Indeed, typical localization of these export transporters are at the blood-brain barrier, placenta, gut, and at the apical side of liver and kidney cells. Two compounds may interact with the same transport protein through induction of expression, inhibition of protein function or competition of substrates. Pharmacokinetics of co-administered drugs can be critically altered when drug-drug interactions occur at the level of the $\mathrm{ABC}$ transport proteins, as distribution and selective excretion of these compounds may depend heavily on $A B C$ protein-mediated transport. This can be 
reflected either in unexpected high blood plasma concentrations potentially causing toxic effects, or subtherapeutic concentrations at the site of action, diminishing therapeutic effects.

It is essential to assure effective blood plasma concentrations upon treatment with anti-malarial compounds in order to cure severely ill patients and prevent resistance acquisition through exposure of the parasite to sublethal blood plasma concentrations. The first-line treatment as recommended by the World Health Organization (WHO) currently consists of artemisinin-based combination therapy [2]. However, resistance against these regimens has been detected and the number of anti-malarials that can be subsequently applied are limited [3]. Toxic effects by unintended elevated blood plasma concentrations, however, should also be avoided.

Direct interaction with $\mathrm{ABC}$ transporter capacity of antimalarial compounds has not been explored in detail. In vitro assays have indicated a possible effect on $\mathrm{P}$ gp-mediated transport or expression after exposure to chloroquine, quinine, mefloquine, primaquine, amodiaquine, piperaquine, artemisinin, and dihydroartemisinin, however, contradictory conclusions concerning the interaction of anti-malarial compounds with $\mathrm{ABC}$ transport proteins could be drawn from different experimental set-ups [4-9]. A possible interaction of anti-malarial compounds with MRP-type transporters and BCRP has also been described [10-13]. Co-administration of anti-malarial compounds with other drug types is highly anticipated. For instance, human immunodeficiency virus (HIV) and malaria co-infections are likely to occur, as there is a high overlap in geographical dissemination [14]. Therefore, the effect of anti-malarial compounds on ABC-mediated transport capacity should be explored in more detail in order to secure the most effective treatment strategies for patients receiving multiple drug regimens.

In this study the direct interaction of a panel of eight well-known anti-malarial compounds (chloroquine, quinine, artemisinin, mefloquine, lumefantrine, atovaquone, dihydroartemisinin, and proguanil) with transport activity of P-gp, MRP1-4, BCRP and BSEP in a vesicular overexpression transport assay have been analysed. Antimalarials $(100 \mu \mathrm{M})$ that caused a decrease in substrate transport larger than $66.7 \%$ were further characterized to determine their $50 \%$ inhibitory concentrations $\left(\mathrm{IC}_{50}\right)$. Potent and previously undescribed inhibition of BCRPmediated transport by atovaquone and P-gp-mediated transport by quinine was observed at concentrations within their therapeutic range.

\section{Methods}

Materials

$\left[6,7-{ }^{3} \mathrm{H}(N)\right]$ Estrone-sulphate ammonium salt $\left(\left[{ }^{3} \mathrm{H}\right]-\mathrm{E} 1 \mathrm{~S}\right.$, specific activity $45.6 \mathrm{Ci} / \mathrm{mmol}$ ), Tauro[carbonyl-3H]Cholic
Acid sodium salt $\left(\left[{ }^{3} \mathrm{H}\right] \mathrm{TCA}\right)(5 \mathrm{Ci} / \mathrm{mmol})$ and $\left[6,7-{ }^{3} \mathrm{H}(N)\right]$ Estradiol 17- $\beta$-D-glucuronide $\left(\left[{ }^{3} \mathrm{H}\right]-\mathrm{E}_{2} 17 \beta \mathrm{G}\right)(34.3 \mathrm{Ci} /$ $\mathrm{mmol}$ ) were purchased from PerkinElmer Life and Analytical Sciences (Groningen, Netherlands). $\left[{ }^{3} \mathrm{H}(N)\right]$-methyl quinidine $\left(\left[{ }^{3} \mathrm{H}\right]-\mathrm{NMQ}\right)(80 \mathrm{Ci} / \mathrm{mmol})$ and unlabelled NMQ [N-methyl-quinidine] were purchased from Solvo Biotechnology (Szeged, Hungary). Bac-to-Bac and Gateway systems, Dulbecco's modified Eagle's medium, GlutaMAX-I culture medium, and foetal calf serum were purchased from Life Technologies (Bleiswijk, Netherlands). Primers were purchased from Biolegio (Nijmegen, Netherlands), and a plasmid purification midiprep kit was from Genomed (Löhn, Germany). Triple flasks $\left(500 \mathrm{~cm}^{2}\right)$ were purchased from Sanbio BV Biological Products (Uden, Netherlands). Estradiol 17- $\beta$-D-glucuronide $\left(\mathrm{E}_{2} 17 \beta \mathrm{G}\right)$, estrone-sulphate (E1S), taurocholic acid (TCA) adenosine 5'-triphosphate magnesium salt (bacterial source), goat-anti-mouse IgG antibody IRDye 800 and goat-anti-rabbit Alexa 680 secondary antibodies, chloroquine $(\mathrm{CQ})$, quinine $(\mathrm{Q})$, artemisinin (ART), mefloquine (MQ), lumefantrine (L), atovaquone (ATO), dihydroartemisinin (DHA), and proguanil (PG) were purchased from Sigma-Aldrich (Zwijndrecht, Netherlands). Protein concentrations were determined with a Bio-Rad protein assay kit from Bio-Rad Laboratories (Veenendaal, Netherlands), and 96-well filter plates were purchased from Millipore (Etten-leur, Netherlands).

\section{Baculovirus generation}

Human P-gp, BCRP, BSEP and MRP1-4 had previously been cloned into the Gateway pDONR221 vector. Sequences matched accession numbers NM_000927, NM_004827, NM_003742, NM_004996, NM_000392, NM_00378, and NM_005845 respectively [15-19]. Some sequences did hold silent mutations of described polymorphisms. Gateway cloning was used to transfer the genes into a VSV-G improved pFastBacDual vector for mammalian cell transduction. The production of baculovirus was executed according to the Invitrogen Bac-to-Bac manual.

\section{Cell culture and transduction}

HEK293 cells were grown to 40\% confluency in Dulbecco's modified Eagle's medium-GlutaMAX-I containing 10\% foetal calf serum at $5 \% \mathrm{CO}_{2}$ in $500 \mathrm{~cm}^{2}$ triple flasks. Culture medium was removed and $25 \mathrm{~mL}$ of medium combined with $10 \mathrm{~mL}$ virus was added and incubated at RT for $20 \mathrm{~min}$, followed by the addition of another $40 \mathrm{~mL}$ of complete medium including $5 \mathrm{mM}$ sodium butyrate to enhance protein expression.

\section{Membrane vesicle isolation and protein analysis}

Cells were harvested three days post transduction by a 5min centrifugation step at $3,000 \mathrm{~g}$. Cells were resuspended in ice-cold hypotonic buffer $(0.5 \mathrm{mM}$ sodium phosphate, $0.1 \mathrm{mM}$ EDTA, $\mathrm{pH}$ 7.0) containing protease inhibitors 
(100 mM phenylmethylsulfonyl fluoride, $5 \mathrm{mg} / \mathrm{ml}$ aprotinin, $5 \mathrm{mg} / \mathrm{ml}$ leupeptin, $1 \mathrm{mg} / \mathrm{ml}$ pepstatin and $1 \mathrm{mg} / \mathrm{ml}$ E-64) and shaken at $4^{\circ} \mathrm{C}$ for $30 \mathrm{~min}$. This lysate was centrifuged 100,000 $x \mathrm{~g}$ for $30 \mathrm{~min}$ at $4^{\circ} \mathrm{C}$, after which the pellet was homogenized in ice-cold TS buffer (10 mM Tris-HEPES and $250 \mathrm{mM}$ sucrose, $\mathrm{pH} 7.4$ ) supplemented with protease inhibitors described before using a tight-fitting Dounce homogenizer for 25 strokes. Two subsequent centrifugation steps at $4^{\circ} \mathrm{C}$ of firstly $20 \mathrm{~min}$ at $4,000 \mathrm{~g}$ followed by supernatant centrifugation for $60 \mathrm{~min}$ at 100,000 g ensured harvesting of the membrane fraction. The pellet was resuspended in ice-cold protease free TS buffer and passed 25 times through a 27-gauge needle to enhance membrane vesicle formation. Protein concentration in these vesicles was determined using the Bio-Rad protein assay, vesicles were flash-frozen in $\mathrm{N}_{2}$ and stored at $-80^{\circ} \mathrm{C}$.

\section{Vesicular transport assays}

A rapid filtration technique that has been described earlier was applied to evaluate uptake of transporter specific substrates into the vesicles; NMQ for P-gp, E1S for BCRP, $E_{2} 17 \beta G$ for MRP1-4 and TCA for BSEP [20]. Briefly, $0.015-0.15 \mu \mathrm{Ci}$ of labelled substrate was combined with unlabelled substrates to a concentration of 0.1-1 $\mu \mathrm{M}$ in a $30 \mu \mathrm{L}$ reaction mixture with $4 \mathrm{mM}$ ATP, $10 \mathrm{mM}$ $\mathrm{MgCl}_{2}$ and $7.5 \mu \mathrm{g}$ total protein membrane vesicles in TS buffer. Transport was allowed by transfer of the plates to $37^{\circ} \mathrm{C}$ during 1-5 min, a time-point within the linear phase of time-dependent transport, as previously determined [15-19]. Hereafter, the reaction was rapidly stopped by placing the plates back on ice and the addition of $150 \mu \mathrm{L}$ ice-cold TS buffer. Samples were subsequently transferred to a 96-well filter plate that had been pre-incubated with TS buffer, and filtered using a multiscreen HTS-vacuum manifold filtration device (Millipore). Filters were washed and extracted, after which $2 \mathrm{~mL}$ scintillation fluid was added to each filter. Radioactive signal on the filters was determined by liquid scintillation counting. Negative controls included eYFP-transduced vesicles and AMP instead of ATP in the reaction mixture.

In the first screen, all anti-malarial compounds were added to the reaction mixture to evaluate transport inhibition at a concentration of $100 \mu \mathrm{M}$. Solvents were used as negative controls, as CQ was dissolved in milliQ, $\mathrm{Q}$ and ART in methanol, MQ, L, ATO and DHA in DMSO and PG in 50\% ethanol. When ATP-dependent uptake was reduced more than $66.7 \%$, the compound was considered a potential inhibitor, and multiple concentrations were tested in the reaction mixture to determine the $\mathrm{IC}_{50}$ value. All concentrations were tested in duplicates or triplicates in two individual biological replicates containing vesicles of independent transductions. Results were depicted and statistically analysed using Graphpad Prism, version
5.03. $\mathrm{IC}_{50}$ values were determined by nonlinear regression analysis of (log) inhibitor-response curves with variable slope. Maximal transport was restricted to $100 \%$, and the minimum was set to be equal or greater than $0 \%$. Statistical analysis was performed using IBM SPSS Statistics 20, applying one-way ANOVA (Analysis of variance).

\section{Results}

Inhibitory profile of anti-malarials against $A B C$ transporter activity

The inhibitory characteristics against the $\mathrm{ABC}$ transporters of eight well-known anti-malarials; CQ, Q, ART, MQ, L, ATO, DHA and PG, was investigated at a $100 \mu \mathrm{M}$ concentration. For each transporter protein, specific radio-labelled substrates were applied to measure ATP-dependent transport into the vesicular overexpression system; N-methyl quinidine (7nM radio-labelled diluted with $90 \mathrm{nM}$ nonradio-labelled) for P-gp, estrone sulphate (74 $\mathrm{nM}$ ) for BCRP, estradiol 17- $\beta$-D glucuronide (150 nM) for MRP1-4 and taurocholic acid $(1 \mu \mathrm{M})$ for BSEP [16-19].

A significant inhibitory effect of $100 \mu \mathrm{M} C Q, Q, M Q$ and PG on P-gp-mediated NMQ transport was observed. CQ reduced NMQ transport to $50 \%(\mathrm{p}<0.001)$ and PG to $76 \%$ ( $\mathrm{p}<0.001$ ), whereas $\mathrm{Q}$ and MQ gave more pronounced inhibitory effects to $15 \%(\mathrm{p}<0.001)$ and $30 \%$ ( $\mathrm{p}<0.001$ ) P-gp-mediated NMQ transport, respectively. ART and DHA slightly induced transport activity to $131 \%$ $(\mathrm{p}<0.001)$ and $112 \%(\mathrm{p}=0.033)$, respectively (Figure $1 \mathrm{~A})$. All anti-malarials inhibited BCRP-mediated estrone sulphate transport activity at $100 \mu \mathrm{M}$ concentrations. Most potent inhibitors were MQ, ATO and PG, which reduced estrone sulphate transport to $8.5 \%, 22 \%$ and $36 \%$ with $\mathrm{p}<0.001$, respectively (Figure $1 \mathrm{~B}$ ). CQ reduced transport to $69 \%$, Q to $45 \%$, ART to $62 \%$, L to $44 \%$, and DHA to $70 \%$ of solvent-exposed BCRP-mediated transport capacity $(\mathrm{p}<0.001)$. Significant inhibition of taurocholic acid transport by BSEP was observed for ATO, which reduced uptake to 54\% ( $<$ < 0.001) and MQ, which reduced uptake to $72 \%$ ( $\mathrm{p}=0.037)$. Furthermore, induction of BSEP transport activity was found for CQ $(117 \%, \mathrm{p}<0.001)$, ART $(117 \%, \mathrm{p}<0.001)$ and DHA $(114 \%, \mathrm{p}<0.001)$ (Figure $1 \mathrm{C})$. MQ was found to have a modest but significant inhibitory effect on estradiol 17- $\beta$-D glucuronide transport by MRP1 as this was reduced to $50 \%(\mathrm{p}<0.001)$, whereas ATO was observed to induce this process to $141 \%$ ( $\mathrm{p}<0.001$ ) (Figure 1D). Induction was also observed for ART and ATO on MRP2-mediated estradiol 17- $\beta$-D glucuronide transport to $151 \%(\mathrm{p}=0.015)$ and $162 \%(\mathrm{p}=0.020)$, respectively. However, no significant inhibition was measured for any of the anti-malarials tested (Figure 1E). MRP3mediated translocation of estradiol 17- $\beta-\mathrm{D}$ glucuronide was significantly inhibited by MQ at a $100 \mu \mathrm{M}$ concentration to $70 \%(\mathrm{p}=0.001)$, whereas ART and DHA induced this process to $122 \%(\mathrm{p}=0.016)$ and $121 \%(\mathrm{p}=0.020)$, 


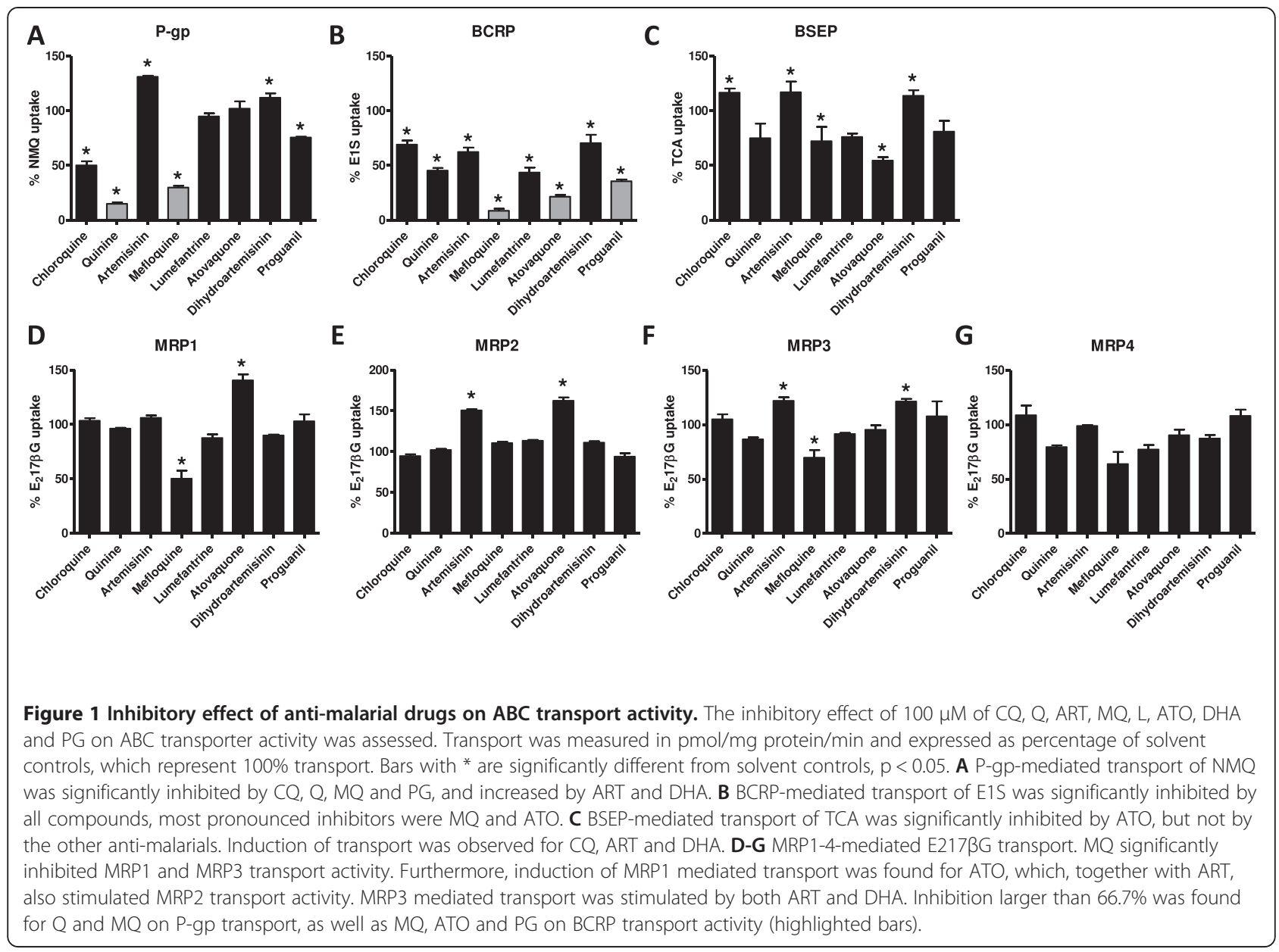

respectively (Figure $1 \mathrm{~F}$ ). No significant estradiol $17-\beta-\mathrm{D}$ glucuronide transport inhibition of MRP4 could be detected (Figure 1F). As the $100 \mu \mathrm{M}$ concentration is not within the physiological range of compound exposure, the most potent inhibitors were selected for further investigation. Inhibition of $\mathrm{Q}$ and $\mathrm{MQ}$ on P-gp-mediated transport, as well as BCRP inhibition by MQ, ATO and PG, were studied in more detail to determine their potencies.

\section{Determination of inhibitory potency of strong inhibitors}

Subsequently, transport inhibition assays were performed for a larger concentration range of Q, MQ, ATO and PG to evaluate P-gp or BCRP activity. Inhibition of transport was measured in a similar fashion applying the same specific radio-labelled substrates. Drug concentrations were logarithmically depicted, and a sigmoidal, inhibitorresponse, variable slope equation was fitted to the data to determine the inhibition curve. Maximal inhibition to $0 \%$ transport was not always reached, which might be due to endogenous transport present in the vesicular membranes.

The strongest inhibitory effect for ATO on BCRPmediated transport was found at median nanomolar range. Transport of estrone sulphate was inhibited with $50 \%$ by this compound at $0.23 \mu \mathrm{M}(95 \%$ CI $0.17-0.29 \mu \mathrm{M})$ (Figure 2A), whereas MQ and PG required the addition of $18 \mu \mathrm{M}(95 \% \mathrm{CI} 17-20 \mu \mathrm{M})$ (Figure 2B) and $118 \mu \mathrm{M}$ (95\% CI 93-148 $\mu \mathrm{M}$ ) (Figure $2 \mathrm{C}$ ) to achieve a similar effect on BCRP activity, respectively. Also for the other compound-transporter combinations, $\mathrm{IC}_{50}$ values were found in the low to median micromolar range. The effect of $\mathrm{Q}$ on P-gp-mediated NMQ transport inhibition was the strongest, and the $\mathrm{IC}_{50}$ was defined at $6.8 \mu \mathrm{M}$ (95\% CI 5.9-7.8 $\mu \mathrm{M}$ ) (Figure 2D). MQ was a less potent inhibitor with an $\mathrm{IC}_{50}$ of $72 \mu \mathrm{M}(95 \%$ CI $49-104 \mu \mathrm{M})$ (Figure 2E). The inhibitory concentration of ATO and $Q$ transport were within the therapeutic range of blood plasma concentrations after both prophylactic and curative anti-malarial dosing.

\section{Discussion}

In this study, the interaction of anti-malarial compounds CQ, Q, ART, MQ, L, ATO, DHA and PG with the activity of P-gp, BCRP, MRP1-4 and BSEP ABC transport proteins were investigated. ATO was found to be a strong inhibitor of BCRP-mediated transport, which has not been described 


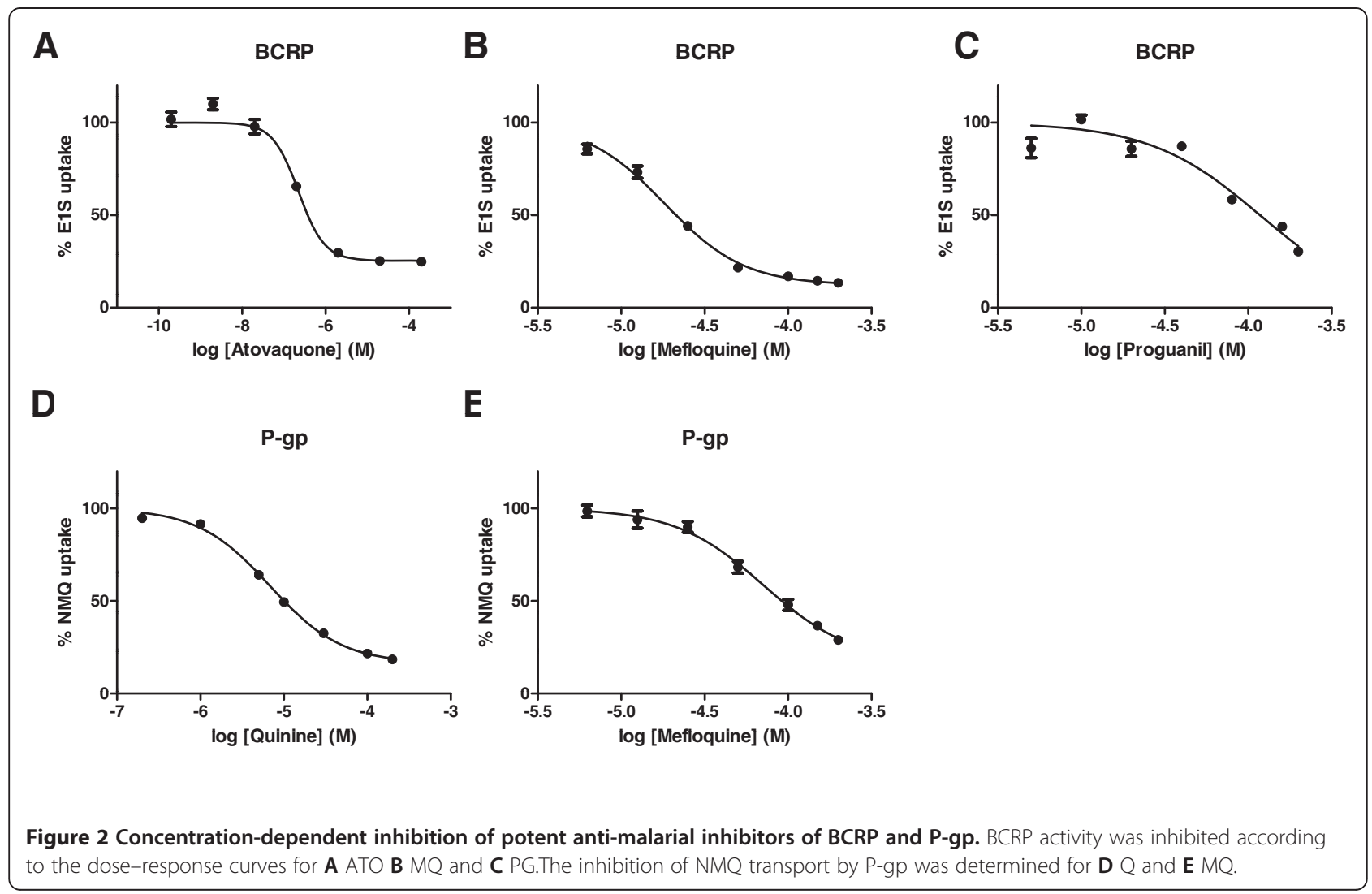

previously. Also Q was identified as a potent inhibitor of P-gp-mediated transport. In addition, subtle alterations on transporter activity have also been identified for other compound-transporter combinations, both inhibitory and stimulating. These interactions can be either competitive or non-competitive. Allosteric interactions that stimulate transport have been observed for several ABC transporters and are substrate dependent, due to which translation of these results to other transporter-substrate combinations is difficult.

A 50\% inhibition of BCRP-mediated transport activity could be achieved with $0.23 \mu \mathrm{M}$ ATO. This concentration is easily reached in blood plasma during both prophylactic and therapeutic use of ATO, as maximal ATO blood plasma concentrations are around $14 \mu \mathrm{M}$ (range 8-26 $\mu \mathrm{M})$ after a daily prophylactic dose of $250 \mathrm{mg}$ [21]. Although the free concentration of ATO is reduced due to its high plasma protein binding, intracellular concentrations at the target site may be higher. ATO is used in a fixed combination with PG in Malarone ${ }^{\circledR}$, which is prophylactively prescribed to travellers, and at higher dosages to treat falciparum malaria, especially in regions of ACT failure [2,22]. BCRP is located primarily on the apical side of excretory organs, and it is highly involved in excretion of xenobiotics from the body [23,24]. As ATO is excreted into bile against steep concentration gradients, involvement of $\mathrm{ABC}$ transport proteins such as BCRP is likely [25] and interactions with ATO can occur when elimination of co-administered therapeutics is inhibited.

Indeed, cases of interactions with ATO have been reported. The azithromycin AUC (area under the curve) and maximal concentrations were lower in all patients when taken in combination with ATO by HIV-1 positive children [26]. Although direct interaction of azithromycin with BCRP has not been investigated, interaction at this level cannot be excluded. Moreover, a clear increase in plasma concentration of etravirine, a reverse transcriptase inhibitor, and saquinavir, a protease inhibitor, was observed in a Caucasian female who started malaria prophylaxis with ATO/PG (250/100 mg) fixed dose combination [27]. Etravirine and saquinavir were prescribed to treat HIV1 subtype B in an antiretroviral combination therapy, supplemented with raltegravir and maraviroc. AUCs, during a 12-hour measurement interval, were increased $55 \%$ for etravirine and $274 \%$ for saquinavir, and peak concentrations after administration of the antiretrovirals was markedly increased. Saquinavir and etravirine have previously been described as potent BCRP inhibitors, but not substrates, with $\mathrm{IC}_{50}$ concentrations of 19.5 and $1.0 \mu \mathrm{M}[28,29]$. Both raltegravir and maraviroc do not inhibit BCRP, indicating that interaction with BCRP is 
specific for saquinavir and etravirine [30]. An alternative or complementary explanation could be interaction at the level of Cytochrome P450 (CYP) enzymes, as PG is mainly metabolized by CYP2C19 but also partly by CYP3A4, saquinavir by CYP3A4 and etravirine mainly by CYP3A4 and to a minor extent by CYP2C9 and CYP2C19 [31-33]. Raltegravir is not metabolized by members of the CYP family, however, maraviroc is a substrate of CYP3A4 $[34,35]$. A strong correlation at this level of drug interaction could therefore not be observed, stressing the plausible role of transporter-mediated drug interactions.

Another study demonstrated a significant decrease in ATO plasma concentration when taken in combination with efavirenz, lopinavir/ritonavir or atazanavir/ritonavir therapy [36]. Interaction at the level of metabolism through glucuronidation was proposed. However, as ATO is only marginally glucuronidated but mostly excreted unchanged into the bile, interaction at the level of $\mathrm{ABC}$ transport proteins and more specifically BCRP could play an important role [25]. Indeed, efavirenz, lopinavir and atazinavir have been described as inhibitors of BCRP-mediated transport [37]. Lopinavir and efavirenz were found to be stronger inhibitors, and correspondingly, ATO concentration was decreased more drastically in these two combinations compared to atazinavir co-administration.

Other pharmaceuticals that interact with BCRP-mediated transport are fluoroquinolone antibiotics, kinase inhibitors, cytostatics, antifolates, and statins [38-44]. Interactions with ATO therapy might be anticipated when co-administered. These drugs are not widely used in malaria-endemic areas, however, interactions with prophylactic doses of ATO used by travellers can be anticipated.

A $50 \%$ inhibition of P-gp-mediated transport by Q was found at a concentration of $6.8 \mu \mathrm{M}$. Indeed, in other in xvitro cellular uptake experiments $Q$ has been described to be both an inhibitor and a substrate of P-gp [4,8,9,45-48]. The concentration at which $\mathrm{Q}$ was effective was lower in the current study than previously described. Most likely this can be attributed to the difference in substrates used. Maximal plasma concentrations reach $30 \mu \mathrm{M}$ during a seven-day regimen of $10 \mathrm{mg} / \mathrm{kg}$ oral dose three times daily of quinine sulphate, and although $\mathrm{Q}$ is bound to plasma-proteins to some extent, clinically relevant interactions at the level of P-gp-mediated transport during quinine treatment may be expected [49].

Interactions with $\mathrm{Q}$ have been described for ritonavir/ lopinavir combination therapy as well as ritonavir monotherapy, and for nevirapine, rifampicin, cyclosporine, and digoxin. Q co-administration with digoxin decreased billary excretion of the latter, indicating specific involvement of transport processes [50]. When co-administered with ritonavir, Q blood plasma concentrations were increased [51]. Ritonavir indeed is both a substrate and inhibitor of P-gp, therefore interaction at this level may explain the increase in Q concentration [52,53]. After rifampicin, nevirapine and lopinavir co-administration, Q blood plasma concentrations were decreased [49,54-56]. Rifampicin interacts with P-gp as substrate, inhibitor and inducer, and lopinavir has been found to inhibit P-gp [57-59]. However, this has not been shown for nevirapine. $\mathrm{Q}$ is one of the oldest anti-malarial drugs still in use, and although it is not used any more in first-line treatment strategy, its use has increased as it is often applied as an alternative treatment after ACT stock-outs [60]. Furthermore, for treatment of malaria infections in pregnant women it is one of the few compounds that can be applied safely [61]. Adherence to this compound is known to be low due to the large range of common and often plasma concentration-dependent side effects [62]. For these reasons, establishing effective but non-toxic blood plasma concentrations is essential in the treatment of malaria, and interaction with co-administered compounds that mediate P-gp transport should be tightly monitored.

Especially, the interaction of both ATO and Q with antiretroviral medication could have severe implications on treatment strategies for both infections, as HIV is another major contributing factor to morbidity, especially in sub-Saharan regions of Africa [14]. Many different antiretroviral compounds are being prescribed, depending on personal characteristics and resistance status, and for many of these compounds interactions with BCRP have been described.

\section{Conclusions}

Anti-malarial compounds can reduce $\mathrm{ABC}$ transporter activity. ATO appeared to be a potent inhibitor of BCRP and $\mathrm{Q}$ of $\mathrm{P}$-gp in vitro. Both compounds inhibited $\mathrm{ABC}$ transporter activity at concentrations equalling prophylactic and effective blood plasma concentrations. Potential involvement in interactions with antiretroviral and antibiotic compounds have been described for ATO and Q, which can be explained by the observed inhibitory effects on BCRP and P-gp transport activity.

\section{Abbreviations}

ABC transporter: ATP binding cassette transporter; P-gp: P-glycoprotein; BCRP: Breast cancer resistance protein; BSEP: Bile salt export protein;

MRP: Multidrug resistance-associated protein; ACT: Artemisinin combination therapy; CYP450: Cytochrome P450; IC50: 50\% inhibitory concentration; 95\% Cl: 95\% confidence interval; HIV: Human immunodeficiency virus; NRT: Nucleoside reverse transcriptase; NNRT: Non-nucleoside reverse transcriptase; PI: Protease inhibitor; CQ: Chloroquine; Q: Quinine; ART: Artemisinin; MQ: Mefloquine; L: Lumefantrine; ATO: Atovaquone; DHA: Dihydroartemisinin; PG: Proguanil.

\section{Competing interests}

The authors declare that they have no competing interests.

\section{Authors' contributions}

SR contributed to the design of the study, the performance of the vesicle transport assays, the analysis of the data and drafted the manuscript. JH executed the vesicle transport assays and helped to draft the manuscript. MV participated in the transport studies and data analysis. RS contributed to the design of the study and critical revision of the manuscript. FR advised in the 
design of the study and adjusted the manuscript. JK conceived of the study, coordinated its execution and helped in the draft of the manuscript. All authors read and approved the final manuscript.

\section{Acknowledgements}

The work of SR is supported by a personal grant from Radboudumc.

\section{Author details}

${ }^{1}$ Department of Pharmacology and Toxicology, Radboud University Medical Centre, Nijmegen, Netherlands. ${ }^{2}$ Department of Medical Microbiology,

Radboud University Medical Center, Nijmegen, Netherlands.

Received: 23 April 2014 Accepted: 22 August 2014

Published: 13 September 2014

\section{References}

1. Borst $\mathrm{P}$, Elferink RO: Mammalian $A B C$ transporters in health and disease. Annu Rev Biochem 2002, 71:537-592.

2. WHO: World Malaria Report 2012. Geneva: World Health Organization; 2012

3. Dondorp AM, Nosten F, Yi P, Das D, Phyo AP, Tarning J, Lwin KM, Ariey F, Hanpithakpong W, Lee SJ, Ringwald P, Silamut K, Imwong M, Chotivanich K, Lim P, Herdman T, An SS, Yeung S, Singhasivanon P, Day NP, Lindegardh N, Socheat $D$, White $\mathrm{NJ}$ : Artemisinin resistance in Plasmodium falciparum malaria. N Engl J Med 2009, 361:455-467.

4. Hayeshi R, Masimirembwa C, Mukanganyama S, Ungell AL: The potential inhibitory effect of antiparasitic drugs and natural products on P-glycoprotein mediated efflux. Eur J Pharm Sci 2006, 29:70-81.

5. Riffkin CD, Chung R, Wall DM, Zalcberg JR, Cowman AF, Foley M, Tilley L: Modulation of the function of human MDR1 P-glycoprotein by the antimalarial drug mefloquine. Biochem Pharmacol 1996, 52:1545-1552.

6. Crowe A, llett KF, Karunajeewa HA, Batty KT, Davis TM: Role of P glycoprotein in absorption of novel antimalarial drugs. Antimicrob Agents Chemother 2006, 50:3504-3506.

7. Burk O, Arnold KA, Nussler AK, Schaeffeler E, Efimova E, Avery BA, Avery MA, Fromm MF, Eichelbaum M: Antimalarial artemisinin drugs induce cytochrome P450 and MDR1 expression by activation of xenosensors pregnane $X$ receptor and constitutive androstane receptor. $\mathrm{Mol}$ Pharmacol 2005, 67:1954-1965.

8. Solary E, Velay I, Chauffert B, Bidan JM, Caillot D, Dumas M, Guy H: Sufficient levels of quinine in the serum circumvent the multidrug resistance of the human leukemic cell line K562/ADM. Cancer 1991, 68:1714-1719.

9. Lehnert M, Dalton WS, Roe D, Emerson S, Salmon SE: Synergistic inhibition by verapamil and quinine of $\mathrm{P}$-glycoprotein-mediated multidrug resistance in a human myeloma cell line model. Blood 1991, 77:348-354.

10. Vezmar M, Georges E: Direct binding of chloroquine to the multidrug resistance protein (MRP): possible role for MRP in chloroquine drug transport and resistance in tumor cells. Biochem Pharmacol 1998, 56:733-742.

11. Stark M, Rothem L, Jansen G, Scheffer GL, Goldman ID, Assaraf YG: Antifolate resistance associated with loss of MRP1 expression and function in Chinese hamster ovary cells with markedly impaired export of folate and cholate. Mol Pharmacol 2003, 64:220-227.

12. Efferth $T$, Olbrich $A$, Bauer R: mRNA expression profiles for the response of human tumor cell lines to the antimalarial drugs artesunate, arteether, and artemether. Biochem Pharmacol 2002, 64:617-623.

13. Bram E, Ifergan I, Shafran A, Berman B, Jansen G, Assaraf YG: Mutant Gly482 and Thr482 ABCG2 mediate high-level resistance to lipophilic antifolates. Cancer Chemother Pharmacol 2006, 58:826-834.

14. WHO: Global Update on HIV Treatment 2013: Results, Impact and Opportunities. Geneva: World Health Organization; 2013.

15. El-Sheikh AA, van den Heuvel JJ, Koenderink JB, Russel FG: Interaction of nonsteroidal anti-inflammatory drugs with multidrug resistance protein (MRP) 2/ABCC2- and MRP4/ABCC4-mediated methotrexate transport. J Pharmacol Exp Ther 2007, 320:229-235.

16. Wittgen $\mathrm{HG}$, van den Heuvel JJ, van den Broek PH, Dinter-Heidorn $\mathrm{H}_{\text {, }}$ Koenderink JB, Russel FG: Cannabinoid type 1 receptor antagonists modulate transport activity of multidrug resistance-associated proteins MRP1, MRP2, MRP3, and MRP4. Drug Metab Dispos 2011, 39:1294-1302

17. Gozalpour E, Wittgen HG, van den Heuvel JJ, Greupink R, Russel FG, Koenderink JB: Interaction of digitalis-like compounds with p-glycoprotein. Toxicol Sci 2013, 131:502-511.
18. Dankers AC, Sweep FC, Pertijs JC, Verweij V, van den Heuvel JJ, Koenderink $J B$, Russel FG, Masereeuw R: Localization of breast cancer resistance protein (Bcrp) in endocrine organs and inhibition of its transport activity by steroid hormones. Cell Tissue Res 2012, 349:551-563.

19. van Beusekom CD, van den Heuvel JJ, Koenderink JB, Schrickx JA, Russel FG: The feline bile salt export pump: a structural and functional comparison with canine and human Bsep/BSEP. BMC Vet Res 2013, 9:259.

20. Van Aubel RA, Koenderink JB, Peters JG, Van Os CH, Russel FG: Mechanisms and interaction of vinblastine and reduced glutathione transport in membrane vesicles by the rabbit multidrug resistance protein Mrp2 expressed in insect cells. Mol Pharmacol 1999, 56:714-719.

21. Thapar MM, Ashton M, Lindegardh N, Bergqvist $Y$, Nivelius S, Johansson I, Bjorkman A: Time-dependent pharmacokinetics and drug metabolism of atovaquone plus proguanil (Malarone) when taken as chemoprophylaxis. Eur J Clin Pharmacol 2002, 58:19-27.

22. Lalloo DG, Hill DR: Preventing malaria in travellers. BMJ 2008, 336:1362-1366.

23. Huls M, Brown CD, Windass AS, Sayer R, van den Heuvel JJ, Heemskerk S, Russel FG, Masereeuw R: The breast cancer resistance protein transporter ABCG2 is expressed in the human kidney proximal tubule apical membrane. Kidney Int 2008, 73:220-225

24. Maliepaard M, Scheffer GL, Faneyte IF, van Gastelen MA, Pijnenborg AC, Schinkel AH, van De Vijver MJ, Scheper RJ, Schellens JH: Subcellular localization and distribution of the breast cancer resistance protein transporter in normal human tissues. Cancer Res 2001, 61:3458-3464.

25. Rolan PE, Mercer AJ, Tate E, Benjamin I, Posner J: Disposition of atovaquone in humans. Antimicrob Agents Chemother 1997, 41:1319-1321.

26. Ngo LY, Yogev R, Dankner WM, Hughes WT, Burchett S, Xu J, Sadler B, Unadkat JD: Pharmacokinetics of azithromycin administered alone and with atovaquone in human immunodeficiency virus-infected children. The ACTG 254 Team. Antimicrob Agents Chemother 1999, 43:1516-1519.

27. Tommasi C, Bellagamba R, Tempestilli M, D'Avolio A, Gallo AL, Ivanovic J, Nicastri E, Pucillo LP, Narciso P: Marked increase in etravirine and saquinavir plasma concentrations during atovaquone/proguanil prophylaxis. Malar J 2011, 10:141.

28. Gupta A, Zhang Y, Unadkat JD, Mao Q: HIV protease inhibitors are inhibitors but not substrates of the human breast cancer resistance protein (BCRP/ABCG2). J Pharmacol Exp Ther 2004, 310:334-341.

29. Zembruski NC, Haefeli WE, Weiss J: Interaction potential of etravirine with drug transporters assessed in vitro. Antimicrob Agents Chemother 2011, 55:1282-1284

30. Zembruski NC, Buchel G, Jodicke L, Herzog M, Haefeli WE, Weiss J: Potential of novel antiretrovirals to modulate expression and function of drug transporters in vitro. J Antimicrob Chemother 2011, 66:802-812.

31. Lu AH, Shu Y, Huang SL, Wang W, Ou-Yang DS, Zhou HH: In vitro proguanil activation to cycloguanil is mediated by CYP2C19 and CYP3A4 in adult Chinese liver microsomes. Acta Pharmacol Sin 2000, 21:747-752.

32. Eagling VA, Back DJ, Barry MG: Differential inhibition of cytochrome P450 isoforms by the protease inhibitors, ritonavir, saquinavir and indinavir. Br J Clin Pharmacol 1997, 44:190-194.

33. Scholler-Gyure M, Kakuda TN, Raoof A, De Smedt G, Hoetelmans RM Clinical pharmacokinetics and pharmacodynamics of etravirine. Clin Pharmacokinet 2009, 48:561-574.

34. Cocohoba J, Dong BJ: Raltegravir: the first HIV integrase inhibitor. Clin Ther 2008, 30:1747-1765.

35. Abel S, Russell D, Taylor-Worth RJ, Ridgway CE, Muirhead GJ: Effects of CYP3A4 inhibitors on the pharmacokinetics of maraviroc in healthy volunteers. Br J Clin Pharmacol 2008, 65(Suppl 1):27-37.

36. van Luin M, Van der Ende ME, Richter C, Visser M, Faraj D, Van der Ven A Gelinck L, Kroon F, Wit FW, Van Schaik RH, Kuks PF, Burger DM: Lower atovaquone/proguanil concentrations in patients taking efavirenz, lopinavir/ritonavir or atazanavir/ritonavir. AIDS 2010, 24:1223-1226.

37. Weiss J, Rose J, Storch CH, Ketabi-Kiyanvash N, Sauer A, Haefeli WE, Efferth T: Modulation of human BCRP (ABCG2) activity by anti-HIV drugs. J Antimicrob Chemother 2007, 59:238-245.

38. Merino G, Alvarez Al, Pulido MM, Molina AJ, Schinkel AH, Prieto JG: Breast cancer resistance protein (BCRP/ABCG2) transports fluoroquinolone antibiotics and affects their oral availability, pharmacokinetics, and milk secretion. Drug Metab Dispos 2006, 34:690-695.

39. Burger $H$, van Tol H, Boersma AW, Brok M, Wiemer EA, Stoter G, Nooter K: Imatinib mesylate (STI571) is a substrate for the breast cancer resistance protein (BCRP)/ABCG2 drug pump. Blood 2004, 104:2940-2942. 
40. Elkind NB, Szentpetery Z, Apati A, Ozvegy-Laczka C, Varady G, Ujhelly O, Szabo K, Homolya L, Varadi A, Buday L, Kéri G, Német K, Sarkadi B: Multidrug transporter $A B C G 2$ prevents tumor cell death induced by the epidermal growth factor receptor inhibitor Iressa (ZD1839, Gefitinib). Cancer Res 2005, 65:1770-1777.

41. Brendel C, Scharenberg C, Dohse M, Robey RW, Bates SE, Shukla S, Ambudkar SV, Wang Y, Wennemuth G, Burchert A, Boudriot U, Neubauer A: Imatinib mesylate and nilotinib (AMN107) exhibit high-affinity interaction with ABCG2 on primitive hematopoietic stem cells. Leukemia 2007, 21:1267-1275.

42. Chen ZS, Robey RW, Belinsky MG, Shchaveleva I, Ren XQ, Sugimoto Y, Ross DD, Bates SE, Kruh GD: Transport of methotrexate, methotrexate polyglutamates, and 17beta-estradiol 17-(beta-D-glucuronide) by ABCG2: effects of acquired mutations at R482 on methotrexate transport. Cancer Res 2003, 63:4048-4054.

43. Matsushima S, Maeda K, Kondo C, Hirano M, Sasaki M, Suzuki H, Sugiyama Y: Identification of the hepatic efflux transporters of organic anions using double-transfected Madin-Darby canine kidney II cells expressing human organic anion-transporting polypeptide 1B1 (OATP1B1)/multidrug resistance-associated protein 2, OATP1B1/multidrug resistance 1, and OATP1B1/breast cancer resistance protein. J Pharmacol Exp Ther 2005, 314:1059-1067.

44. Maliepaard M, van Gastelen MA, Tohgo A, Hausheer FH, van Waardenburg $R C$, de Jong LA, Pluim D, Beijnen JH, Schellens $J H$ : Circumvention of breast cancer resistance protein (BCRP)-mediated resistance to camptothecins in vitro using non-substrate drugs or the BCRP inhibitor GF120918. Clin Cancer Res 2001, 7:935-941.

45. Borgnia MJ, Eytan GD, Assaraf YG: Competition of hydrophobic peptides, cytotoxic drugs, and chemosensitizers on a common P-glycoprotein pharmacophore as revealed by its ATPase activity. J Biol Chem 1996, 271:3163-3171.

46. van der Sandt IC, Blom-Roosemalen MC, de Boer AG, Breimer DD: Specificity of doxorubicin versus rhodamine-123 in assessing P-glycoprotein functionality in the LLC-PK1, LLC-PK1:MDR1 and Caco-2 cell lines. Eur J Pharm Sci 2000, 11:207-214.

47. Wang EJ, Casciano CN, Clement RP, Johnson WW: Active transport of fluorescent P-glycoprotein substrates: evaluation as markers and interaction with inhibitors. Biochem Biophys Res Commun 2001, 289:580-585.

48. Nagy H, Goda K, Fenyvesi F, Bacso Z, Szilasi M, Kappelmayer J, Lustyik G, Cianfriglia M, Szabo G Jr: Distinct groups of multidrug resistance modulating agents are distinguished by competition of P-glycoprotein-specific antibodies. Biochem Biophys Res Commun 2004, 315:942-949.

49. Pukrittayakamee $S$, Prakongpan S, Wanwimolruk S, Clemens $R$, Looareesuwan S, White NJ: Adverse effect of rifampin on quinine efficacy in uncomplicated falciparum malaria. Antimicrob Agents Chemother 2003, 47:1509-1513.

50. Hedman A, Angelin B, Arvidsson A, Dahlqvist R, Nilsson B: Interactions in the renal and biliary elimination of digoxin: stereoselective difference between quinine and quinidine. Clin Pharmacol Ther 1990, 47:20-26.

51. Soyinka JO, Onyeji CO, Omoruyi SI, Owolabi AR, Sarma PV, Cook JM: Pharmacokinetic interactions between ritonavir and quinine in healthy volunteers following concurrent administration. Br J Clin Pharmacol 2010 69:262-270.

52. Choo EF, Leake B, Wandel C, Imamura H, Wood AJ, Wilkinson GR, Kim RB: Pharmacological inhibition of P-glycoprotein transport enhances the distribution of HIV-1 protease inhibitors into brain and testes. Drug Metab Dispos 2000, 28:655-660.

53. Yamazaki M, Neway WE, Ohe T, Chen I, Rowe JF, Hochman JH, Chiba M, Lin JH: In vitro substrate identification studies for p-glycoprotein-mediated transport: species difference and predictability of in vivo results. J Pharmacol Exp Ther 2001, 296:723-735.

54. Soyinka JO, Onyeji CO, Omoruyi SI, Owolabi AR, Sarma PV, Cook JM: Effects of concurrent administration of nevirapine on the disposition of quinine in healthy volunteers. J Pharm Pharmacol 2009, 61:439-443.

55. Uriel A, Lewthwaite P: Malaria therapy in HIV: drug interactions between nevirapine and quinine. Int J STD AIDS 2011, 22:768.

56. Nyunt MM, Lu Y, El-Gasim M, Parsons TL, Petty BG, Hendrix CW: Effects of ritonavir-boosted lopinavir on the pharmacokinetics of quinine. Clin Pharmacol Ther 2012, 91:889-895.

57. Fardel O, Lecureur $V$, Loyer $P$, Guillouzo A: Rifampicin enhances anti-cancer drug accumulation and activity in multidrug-resistant cells. Biochem Pharmacol 1995, 49:1255-1260.
58. Collett A, Tanianis-Hughes J, Hallifax D, Warhurst G: Predicting P-glycoprotein effects on oral absorption: correlation of transport in Caco-2 with drug pharmacokinetics in wild-type and mdr1a(-/-) mice in vivo. Pharm Res 2004, 21:819-826.

59. Geick A, Eichelbaum M, Burk O: Nuclear receptor response elements mediate induction of intestinal MDR1 by rifampin. J Biol Chem 2001, 276:14581-14587.

60. Yeka A, Achan J, D'Alessandro U, Talisuna AO: Quinine monotherapy for treating uncomplicated malaria in the era of artemisinin-based combination therapy: an appropriate public health policy? Lancet Infect Dis 2009, 9:448-452.

61. WHO: Guidelines for the Treatment of Malaria. Geneva: World Health Organization; 2010

62. Taylor WR, White NJ: Antimalarial drug toxicity: a review. Drug Saf 2004, 27:25-61.

doi:10.1186/1475-2875-13-359

Cite this article as: Rijpma et al.: Atovaquone and quinine anti-malarials inhibit ATP binding cassette transporter activity. Malaria Journal 2014 13:359.

\section{Submit your next manuscript to BioMed Central and take full advantage of:}

- Convenient online submission

- Thorough peer review

- No space constraints or color figure charges

- Immediate publication on acceptance

- Inclusion in PubMed, CAS, Scopus and Google Scholar

- Research which is freely available for redistribution 